\title{
Decolonial Counter-conducts? Traces of Decentering Migrant Ecclesiologies
}

\author{
Trygve Wyller
}

\begin{abstract}
Decolonialisation concerns theology. As long as theology is preoccupied with engaging or explaining the other, it is not a decolonial project. As such this article makes a connection to Walter Mignolo's claim that the researcher as much as the subject needs to be interrogated as part of the research in order to disrupt the subject/ object binary of colonial knowledge traditions. The main part of the article presents three narratives from the life of Nisha, a refugee woman from the DRC living in a South African township. The narratives also involve a researcher - I, the professor - and the pastor and gatekeeper that introduced Nisha to me. In all of the narratives, the two traditional subjects (professor and pastor) are decentered. Nisha makes money trading from a small kiosk, and she invites the two men to a meal at her township house. She walks the pastor and the professor through the neighborhood where she lives. Building on Michel Foucault`s theories of counter-conducts, the article argues that the three decentering narratives present Nisha's everyday practices as counter-conducts and the two men as the decentered others. The article argues that such a decentering performs traces of a decolonialising theology. God is the one that lets hierarchy decenter in order to open spaces of others.
\end{abstract}

Keywords: Counter-conducts, decoloniality, ecclesiology, migration, pastoral power

\section{Introduction}

This article will discuss how everyday migrant practices present surprising traces of a decolonial ecclesiology. Ecclesiology is a field that entails scholarly discussion of what the church is and what it might be. While one might think 
one knows what church is, this article insists that we do not know. If there is no element of surprise, then we are probably not engaged in discussion of what church is or what it might be. Accordingly, what is needed is a discourse where church may be discovered in surprising places and in unexpected contexts. The element of surprise is not new in Protestant/Lutheran theology, but what is new in this article is that the surprise is a key characteristic of an ecclesiology that one could label as decolonial.

The basic argument is that an unexpected or surprising ecclesiology needs to start from below. Here there are practices that are not merely relevant to the field, but that are also decisive when exploring what ecclesiology is. In this, one needs to sense the surprise, which can only be made manifest in encounters. This attitude of starting from below, however, belongs to a broader movement. Based on a substantial critique of church and religion, Walter Mignolo (2011) has developed what he calls a decolonial approach.

The decolonial is an explicit resistance to colonial hegemony in modernity. The decolonial entails a perspective from below, as well as a focus on practices, the indigenous, the local, and the everyday, especially in the Southern contexts. Mignolo calls the decolonial 'border thinking' (Mignolo 2011), signaling the epistemological shift that develops when bodies, spaces, and the local are points of departure for thinking. Instead of the post-colonial, an invention of French philosophy, the decolonial is centered on resistance. This is a different discourse; the discourse Foucault called subjugated knowledge (Mignolo 2011). This is why location and context are as decisive as the concepts themselves. Mignolo draws on the French linguist Emile Benveniste and his distinction between enunciation and the enounced. Enunciation includes the subject speaker in the meaning process of the enounced (Mignolo 2011). The local and the embodied receive significant epistemological priority in this interpretative process.

The intention in this article is to introduce a theological connection to Mignolos's concept of 'thinking with'. Referring to the Ecuadorian historian Arturo Escobar, Mignolo and Walsh write:

First, Escobar made a case for the 'flesh and blood' of decolonial struggles; of the need for potential work within what he termed 'the modernity/ coloniality research program. Here Escobar referred to the work that directly engages 'colonial differences and border thinking from the ground up' (Escobar in Mignolo \& Walsh 2018:27). 
Such a shift entails a rethinking of how and with whom we think (and understand) theory, and a recognition of the convergence of local histories, knowledges, and political praxis. As I have argued above, it also entails moving from a posture of 'studying about' to 'thinking with'. This latter move necessarily demands 'the enunciation of the researcher herself or himself, and making visible his or her presence in his thinking' (Mignolo \& Walsh 2018:28). The challenge in this article is to examine what this decolonial approach might mean for theology, especially in relation to ecclesiology. Mignolo and Walsh do not express any expectation of churches or of theology. For them, churches represent one of the main pillars of the colonial. Their focus, rather, is the local everyday praxis of living by those who live the colonial difference. In this regard they note that we proceed as

engaged intellectuals still learning to unlearn in order to relearn; to challenge our own histories, herstories, privileges, and limitations ... [thus] decoloniality means thinking, doing, sharing, and collaborating with people in different parts of the globe engaged in similar paths, people striving - as both of us are - in their own local histories confronting global designs (Mignolo \& Walsh 2018:245).

In my view, this is a position that can offer a valuable contribution to theology, and eccelsiology. One important goal of Protestant theology is to look for the unexpected. If we follow Mignolo and Walsh, the unexpected is out there, it is located in the epistemological shift to 'border thinking'. Therefore, I will start with three short stories from the life of Nisha - woman I encountered while conducting fieldwork in South Africa (Wyller 2018; 2019).

\section{The Nisha Narratives}

In most South African cities, there are a significant numbers of refugees from neighboring African countries such as Malawi, Zimbabwe, and the Democratic Republic of the Congo. While tourists might not notice them, locals do. Many of these migrants own barbershops, cafes, or other small businesses. A testimony to hostilities, many locales call these migrants 'makwerekwere' (foreigners).

This article will outline and deconstruct three narratives from the life of one such migrant, Nisha, to illustrate how 'border thinking' informs and 
shapes theology. Nisha is a recently widowed 34 year old refugee from the Democratic Republic of Congo (DRC). Today she lives with her four children in a township in a medium-sized South African city. In this township, the majority of families are Zulu, and natives of this part of the country. In general Zulu's do not speak Swahili and Nisha does not speak their language - isiZulu - either. In addition to a generally hostile attitude towards 'foreigners' language problems makes everyday connections between many migrants and locals difficult. For Nisha every day starts at 4.00 a.m. when she rises to light the fire and start cooking for her family. She sends three of her four children to school, leaving the smallest with family that lives nearby. She then goes off to buy fruits and sweets that she sells in a small kiosk, known locally as a spaza. When her husband was still alive, he worked in a small barbershop situated on the same street corner where Nisha now works.

Nisha is an evangelical Christian, but in her present exile in South Africa, she spends most of her energy participating in a refugee ministry, focused on Swahili/French speaking people from countries such as the DRC, Burundi, and Rwanda. 'The ministry encourages you to survive' Nisha said to me, underlining that the people she meets in church have become like family to her. The refugee ministry is led by a resourceful and very experienced pastor - Yannick - who facilitates Nisha`s every day participation in the church.

During the week pastor Yannick attends to social issues that concern migrants and he invites them to Congolese, ecumenical services in a local church building on Sunday afternoons. The service takes place in the afternoon, so that the migrants, should they choose to do so, can attend the morning services of the local churches in their own denomination. The ecumenical afternoon service attends also to ethnic and cultural aspects of life. It follows a regular structured liturgy of a word of welcome, local music and singing, sermons, testimonies and prayers, offerings, and general practical information. After the service, biscuits and mineral water is served in the church room. In this way, the service is similar to mainline Protestant services in South Africa. However, the clothing, language and music are not the same, and contribute to maintaining a strong and particular cultural identity. This seems also seems to be one of the main goals of the service.

In the church services drums are played throughout, while women wearing their various traditional attire carry small children on their backs. I imagine that for those who attend, it may feels as though they are in the DRC for that short period of time. This is a cultural and life-world experience, 
located within a church context. On Sundays the church emphasises cultural belonging, although on weekdays the situation is different. During the week, refugees of different national and cultural origins are thrown into a SouthAfrican cultural and social context. They gather in small groups, standing on the street corners selling their goods such as sweets, fruit and mobile phone covers to passers by. These migrants can be found all over most South-African cities, and they are an integral part of the inner city sensibilities, always there, making money from trading or running small businesses.

I was introduced to Nisha by pastor Yannick while I was living in the area and wanted to meet and speak with people living as refugees in South Africa. Having done research on irregular migration in Europe, my intention was to collect refugee experiences that could lead to elaborations on church/refugee relations in this part of Africa. The initial interest was tied to the way in which ministries such as the one led by Pastor Yannick impacted on or enhanced the everyday life of refugees. As such I went into the first meting with Nisha with the rather traditional expectation of getting access to 'interesting material.' Pastor Yannick is himself a refugee, having come to South Africa from one the countries neighboring the DRC. Having settled in this medium-sized South African town, he has spent several years building his ministry, with support and connections from abroad, especially from the US.

My first meeting with Nisha took place at one of the Sunday services. Nisha was among those attending, and she stood out as she sang with a strong and emotive voice. I asked pastor Yannick if he could arrange for me to meet Nisha at her house and conduct some tape-recorded interviews with her. I still have the tapes from these interviews, but after several meetings over three years, I am convinced that the most important information from Nisha`s life does not come from the interviews, but from my direct encounters with her and her everyday life. The three narratives I recount below are intended to introduce some of these encounters and offer glimpses of why an embodied everyday might be theologically much more relevant and significant than taperecorded interviews.

\section{Narrative One: Selling}

Nisha makes her living selling goods from a kiosk to the locals passing by. The kiosk space is also where she lives - it is her social life. People pass by and some make purchases, some with friendly hellos, others more skeptical. The 
kiosk is on a street corner where other refugees live, meaning that she is also somewhat protected.

The kiosk project emerged from pastor Yannick`s relation to a European aid organisation and the micro credit system built by that organisation. Pastor Yannick lent some money to Nisha, which she used to start the kiosk. When the kids come home from school, they often gather around the kiosk, while other family members pass by chatting. While the space offers a social space for refugees, there are also non-Swahili speaking locals who buy from the kiosk. When they arrive the small talk is reduced, and customers point at the fruits or the sweets they wish to buy. Nisha wraps the goods in a plastic bag and receives the money before handing over the bag. These transactions with locals are quick, while those with other refugees and their families are more lengthy, and resemble a gathering of friends where the selling is less important than the encountering.

The space is hot and dusty. There is a small roof above the kiosk that Nisha can sit under when the heat becomes too much. This is a way of life that provides a living, but it also seems to be contributing to social life and encounters with family, neighbors, and friends. The selling is at the centre of Nisha`s everyday; it is her main activity between morning and mid-afternoon. Originally, the kiosk was supported by the church established micro-credit, yet when pastor Y and I visit the kiosk we make sure to not to come too close and interrupt or disturb the trading. Nisha never says, but she seems to appreciate that we stay in the background. This is her social life, not ours. The ministry and the pastor are facilitators, but Nisha is the kiosk subject. It is her skin that sweats in the heat; it is her relations that are developed during the many small encounters at the kiosk.

\section{Narrative Two: Eating}

Fascinated by her role in the Sunday service and in the everyday interactions at the street corner kiosk, I decided to deepen my engagement with Nisha, recognising her as a significant representative of refugee life in South Africa. Pastor Yannick acted as a gatekeeper or sponsor for me, and together we went to visit Nisha in her township house on the outskirts of the city. We first met for an interview in early 2016.

Townships in South Africa tend to be crowded areas, full of neighbors, dogs, kids and small businesses. As a white European researcher I am the 
outsider, and I feel almost like an alien as I meet with Nisha. Nisha is in her living room surrounded by her youngest kids and her neighbor, all sitting in the redskin sofa. The room we are in is separated from the other rooms with a type of colorful curtain. On the left wall there is a TV, and on the other sofa sits the pastor - Yannick - and the professor $-\mathrm{I}$. The interview lasted for about 90 minutes.

Nevertheless, it is not the interview I remember, it is the meal that followed the interview. The meal was a gift from Nisha to Pastor Yannick and myself after the interview was done. As I turned off the recorder, and was just about to leave, Nisha asked: 'Maybe you would like to eat before leaving?' In that moment I considered everything from research ethics to theories of gifts that I had read, as well as orientalist reports of how township food is unhealthy for fragile Whites. Yet in less than a second, I replied with a firm and polite confirmation; I would be delighted to eat.

Hence we proceeded to eat a Congolese fish dish, while talking about nice things, sharing stories and showing photos of family and life. This was, in my memory today, the most exceptional and significant moment of my whole visit. Nisha narrated that she, and her neighbor, had been preparing the meal from very early morning, something she had not said when I first entered her house. What I remember the most is the smell of the fish dish, the intense red color of the tomato sauce, the large bowl of rice, and the intimate space and embodied engagement when Nisha shared the food between all of us. I also remember clearly the emotional relief following the formal 90 minute interview, the character of the Swahili voices (for me an unfamiliarly 'thin' phonetic), and the visibilities (colors, nature peering in from the outside, women breastfeeding on the sofa) and most of all; being united in a new and unexpected community through the meal offered to us by Nisha. In that moment there was no doubt, Nisha was in charge, she took the lead, and the professor and the pastor were guests and strangers. The hierarchy from the interview was turned upside down. It was a different hierarchy, constituted by senses and emotions.

\section{Narrative Three: Walking}

The third Nisha narrative is the most recent, it is from early 2018 when I made one more visit to the South African town, and meet with pastor Yannick and Nisha. Like the other narratives, this is also a narrative about senses and being 
sensed as the core of an intentionality relation. While the subject is still Nisha, the focus of this narrative is on walking, rather than eating.

One year after the meal described above, I was again invited to visit Nisha`s township house. Again I interviewed her, for more than 90 minutes, and again there were smells like the first time. The room however, was different as Nisha had moved into another room since the last time I saw her. After we completed the interview I asked Nisha; could we go for a walk through the township neighborhood? What I did not know was that this was Nisha`s first walk through the township since her husband died. A few months before this narrated walk, her husband, also a refugee from the DRC died suddenly died from a brain stroke - several weeks after he was assaulted and beaten by Zulu neighbors. The area is known for hostility to African migrants and has a high incidence of xenophobia.

Like during the meal, pastor Yannick and I walk with Nisha and are directed by her. However, this time, it is more challenging to determine who among us is the stranger; me the foreign white professor, or her the widowed migrant woman. The sensory experience connects us, of course, yet, the experience of being disconnected stays in the walk. It was Nisha who decided where to walk, the pace, as well as whom we should visit. Nisha appeared to enjoy meeting neighbors and friends, and she did not notice us falling behind, in fact, she seemed uninterested in us. Nisha, on her walk, reconquered the space, while the pastor and the professor were left behind. Nisha lead this walk of reconnecting, of hugging her DRC neighbor, who upon seeing Nisha approach ran to her house to prepare it before the friend (and the pastor and the professor) visited. Inside the house, we shared the smells and all the sounds and voices of friendly talking. Nevertheless, by pastor Yannick and myself always trailing behind Nisha, walking two or more steps behind, it was as if there was a movement of disconnection taking place.

The pastor and the professor are invited in but kept at an 'intimate' distance so that they can witness but not determine or direct the rhythm of the walk. We are kept at a distance, but in that distance, we are not unnoticed. We, and especially I as the white professor, are aliens in this context, noticeable for sure, also because we are behind Nisha the whole time. The walk is Nisha's agency walk, where she pushes the pastor and the professor to the margins as strangers, almost into the abyss of being aliens once again. Once again, the sensory is at the centre; the dust, the heat, the sweating of the skin, and cries of joy welcoming Nisha as she walks in front. 


\section{Discussion}

In the tradition of the decolonial, the everyday and the practices of ordinary people have been given strong significance. The question is, however, whether Nisha`s everyday agency has a theological or ecclesiological significance. This is a demanding and important question. On the one hand, there is no doubt that all three stories narrate practices in a context of ministry, church and Christianity. Pastor Yannick facilitates them all; the participants belong to a community of evangelical believers and refugees among whom God has authority. On the other hand, the selling, the eating, and the walking represent a move away from both ministry, church and Christianity. Here Nisha (and her refugee friends) strengthen their agency, while the minister and the professor decrease in significance. This is what the narratives communicate.

In the following discussion the focus is on whether decentering represent traces of a decolonial theology, merely through the decentering of the minister and the professor of theology. The element of surprise is too often is neglected in empirical studies of church and theology, and perhaps one of the biggest surprises is to understand and discover how decentering and disrupting implies a lot more than a mere fading away. The first step is to look more closely at aspects of three narratives. The first is the related to space.

\section{a. Selling as Decentering}

Jennifer Greenburg (2010) has discussed spatial practices among Congolese migrants in Johannesburg. Her point of departure is what she calls 'the spatial politics of xenophobia,' referring to the spate of xenophobic violence in 2008. For Greenburg the implicit politics of xenophobia is spatial:

The violence and cultural racism to which migrants are subjected, combined with volatile housing conditions, has the effect of continually displacing migrants within the city (2010:67).

The reason for this displacement is that racist aggression makes it impossible for migrants to stay in one place for an extended period. They are not safe in any one place. Moving therefore becomes a permanent trajectory for refugee people.

Migrant trajectories within the city point to the production of a new relationship between race and space through which the violent racism 
to which migrants are subjected at the same time as they are forced to remain constantly on the move (Greenburg 2010:67).

Following other migration scholars, Greenburg points to the significance of Pentecostal churches for the refugee population in South Africa. On the one hand, the spatial politics of xenophobia reduces spatial belonging and forces migrants to remain on the move, never settling permanently. On the other hand, religion takes people back to space. Her research shows that,

Pentecostal churches are some of the most important sites at which urban space is being reconfigured .... The church is one of the everyday practices that produce migrants' spatial and racial experiences of the city (Greenburg 2010:78).

The selling narrative I outlined above disturbs Greenburg`s interpretation from the side of church. Greenburg takes the church space for granted and sees it as a space that enhances the social life and the security of the migrants. The Nisha narrative, however, opens a new discussion of what church is. Pastor Yannick is undoubtedly the church leader for Nisha. He is also the facilitator of her kiosk business, providing her with the necessary microcredit. Nevertheless, both the pastor and the professor remain distant in the trading process. It is Nisha's business, the business is not a practice that succeeds because the ministry is behind it.

Like suggested by Adogame (2010) and Settler (2018), writing about similar contexts, the kiosk space is a subculture of relations, where stories are shared and challenges are addressed. Reconfiguring space is a phenomenon that gives agency; agency happens because refugee women, locals, neighbors, family and kids relate and connect. My focus here is: Yes, this is a reconfiguretion, but what is reconfigured the most is the church itself. Nisha takes the lead; the pastor is at a distance. Greenburg, Adogame and Settler make important arguments when pointing to reconfiguration in a township context. Ministries and churches are unwittingly involved in trading and exchange, and as such breed new spaces of subcultural power. However, if the analysis is too occupied with this type of spatial change, we will lose sight of how practices of selling open new perspectives on what church is. Church might be something more, and it might be different, from what mere observation can tell us. 
The narrative of selling might seem like a very trivial and orientalist ethnographic report from my visit to the strangers. Nevertheless, the narrative is more than trivial and to call it orientalist is only part of the story. It moves beyond both the trivial and the orientalist. It is a narrative about the church facilitating and decentering, and it is about an agency that is conditioned by embodied interconnectivities. The methodological challenge is that it is not possible to just 'report' from third space, from the heterotopias, the reporting itself leads to the orientalism. Merely reporting misses the third space and in a sense even rejects it. This is one aspect of the needed methodological reflection noted in the first part of this article. Mignolo (2011) underlines that 'border thinking' implies to 'reflect with' people and that such a reflection requires one to be open about the researcher`s own role and - in this selling narrative - how the researcher is kept at a distance when selling is the main activity.

\section{b. Eating as Decentered Sharing}

The meal experience reveals that, when the researcher reflects on her or his role as part of the third space, a new and decisive level of interpretation opens up. In the following section, I make connections to the work of Sara Ahmed, although other phenomenologists might also be relevant to the discussion. Ahmed (2000) criticises Levinas as belonging to a tradition that 'fetishises' the other. For Levinas the other is unreachable, different, and therefore unable to be connected to. Of course, we all know that Levinas takes an ethical position absolutely opposite to that of the othering. However, the tendency to essentialise others is part of the same trajectory. We effectively disconnect from them.

The point is that such othering, according to Ahmed (2000), can be avoided if we include a consideration of the social encounter; the touch, the smell, and the voice, the sensibilities that we cannot but recognise. Ahmed, therefore, distinguishes between being an alien and being a stranger. An alien is someone that we do not sense. The alien is outside and cannot be sensed or be made sense of. The stranger is different. The stranger does not belong to my neighborhood or my family, still the stranger is a person I sense, as in someone I detect through my senses. The senses connect persons, even if the other is outside my tribe.

The decisive aspect of the meal narrative is that the other was not Nisha, it was I, the white professor/researcher. The meal made him a stranger, 
but not an alien. The meal sensibilities, the seemingly everyday trivialities of eating are also significant in how people are sensibly connected. Just sitting in the township living room increased the sensible transformation from alien to stranger, but the meal confirmed it by being the sensible core event in the whole meeting.

This analysis, then, explains and interprets why Nisha is defined as sharing. It is a sharing of senses and because of that a sharing that connects and at the same time disturbs the subject/object hierarchy. The meal narrative, then, is part of the decolonial process, introduced by Mignolo. The epistemological disobedience is initiated when the meal is the reflective starting point. Choosing the meal as the starting point implies that this form of sharing also gives epistemological priority to the senses and to the emotions connected to them. Moreover, this means that Nisha is a first rank epistemic contributor.

\section{c. Walking as Decentered Agency}

When Nisha walked through the township where she lived one morning in early 2018, the smells, colors, and heat were the same as every day. However, at the same time, nothing was everyday about this walk. It was a new everyday, it was Nisha`s first walk through the township since her husband died. Nisha`s dramatic refugee journey (which included many years in different violent refugee camps in Tanzania) eventually brought her to South Africa where she settled down. A few months before the 2018 walk her husband, also a refugee from the DRC, died suddenly from a brain stroke. The family suspects that the husband`s stroke was provoked by an assault some weeks before when he was beaten by hostile Zulu neighbors.

That specific day, Nisha did not walk alone, yet, she was in the lead. The Swahili-speaking pastor, and the researcher narrating this story, walked with her. The Swahili pastor was the facilitator of the meeting, but in the walk was second in line. Nisha leads, the pastor and the professor follow. This everyday belongs to Nisha.

There is no altar and no other classical ecclesial signs in the Nisha walk, but there is an obvious joy of encountering. Before the walk, there were months of isolation since her husband passed away, but on the walk Nisha reconquers the space. On this walk we are, in a way, decentered from both church and traditional hierarchies of power. Roles are inverted, gender, power 
and spirituality are not in someone's specific property. It is a disruption and a decentering of what used to be called theological discourse and of what used to be conceptualised as church. The fundament is that Nisha takes the lead and performs agency in the midst of the sensory everyday walk. This significant agency, walking two steps ahead of the pastor and the professor, embodies traces of a decentering ecclesiology. Nisha is the one who sets and keeps the rhythm and the pace; she is the one who determines what her co-walkers should see. Through that walk, she constructs a script that initiate traces of the decolonial. Moreover, these traces have ecclesiological implications. Freedom walk; nothing but that is what the church ought to do.

Translated into the phenomenology of Sara Ahmed, the walking narrative differs from the eating narrative, in one significant way. The decentering, the walking two steps behind, alienates the ecclesial power-people. The invitation to lunch inverts roles, yet recognises the sensory connections so that the power-people participate as recognised strangers, not as aliens. In the walking narrative, the disruption is more significant. There is still a connection between Nisha and the two others, but the two become increasingly alienated from her. The pastor and the professor belong to the same space, but are located further towards the margins than they were in the eating narrative.

These three short Nisha narratives are attempts at providing a way to restart theology. The selling narrative focuses on the exchange and trading that puts Nisha in charge. The meal is about taking part in a subculture of sharing, of sensory experiences, and of a reversal of roles. Finally, the walking embodies a new power structure between the three walking figures, Nisha, pastor Yannick and I - the white professor. All three narratives point in the same direction, wherein the involvement of the researcher is a necessity for restarting a reflective decolonial theology. Involving here means focusing on the everyday of refugees and locals, and letting this involvement be the epistemic priority. This could mean that theology can give important contributions to decolonial thinking, resulting in a decolonial move in theology itself.

\section{Decentering Ecclesiology as Counter-conduct}

Epistemological violence is one of the more serious diseases in contemporary, critical research. While no one wishes to do it, a lot of us still do. This is also true for theology, not least because it wishes to do more than just well, to help more than many, and to improve societies to be better than anyone else. The 
challenge is that theology was Michel Foucault`s main source when he analysed and interpreted pastoral power (Foucault 1982). Theology and religious discourse are archetypical performances of what epistemological violence is in the discipline; the power hidden behind good intentions, and the lack of space for critical resistance.

Nevertheless, we tend to forget that it was Foucault himself who also came up with an exit from the pastoral power-trap. Foucault is famous for his almost deterministic analysis of power discourse and power practices. Still, he also offered traces for a possible resistance. There is not only pastoral power; there are also counter-conducts (Foucault 2007; Sander, Villadsen \& Wyller 2016). What is interesting is that Foucault located the origin of counterconducts in what he called millenarian contexts, that is religious practices located in late medieval mysticism and eschatological thinking. In other words, the idea that theology can contribute to counter-conducts comes from Foucault himself.

Nisha`s selling, eating, and walking are as far from millenarian, late medieval mysticism as possible. Nevertheless, the three narratives narrate a decentering practice that embodies and visualises what the ecclesial surprise might be; an inversion of roles, a sharing of sensory experiences, and the epistemic priority of the vulnerable and their agency. This is the start of a theology less obvious than the one in the eschatological universe where Foucault saw the origin of counter-conducts. However, it is still the (theological) author (of this article) that discovers this new origin. If there is a mysticism or a transcending religiosity in the messages of the narratives, it is in the decentering traces of an ecclesiology of the everyday, and the spatial phenomena of the everyday. The religion of the counter-conduct disrupts traditional religious discourses. Here, new agents and more risky Gods develop. The theological surprise is that there are still practices and messages that set people free. The setting free is the miracle; the church, the ministry, and the professor facilitate, but in the end they disappear and Nisha appears as the subject.

In Foucault's view, classical pastoral power developed within the medieval monasteries where the abbot leader was in total control of the well being of his monks. Fundamentally based on the power to save the souls of his humble suppressors, the abbot also had the power to facilitate the material parts of their life, housing, the regulation of the day, duties and relation to the life outside the monastic walls (Sander et al. 2016; see also Foucault 1982:782).

It is well known that Foucault claimed that the classical pastoral power 
became transferred into more modern, and seemingly less monastic, welfare state. Foucault (1994) labeled this governmentality, which for him was the secularised version of pastoral power. The welfare regime also had the power to give sense, and to control the 'soul' of its users. At the same time, the welfare state provided people with sufficient material goods, subsidies, accommodation, economic support etc.

The surprising element in the narratives, as I have interpreted them, is that the traditional Foucauldian pastoral power seems to be the content of all three. At least until one re-examines them; all three narratives presuppose pastor Yannick and the white professor as the two persons in charge. As the agents of traditional pastoral power, they enhance the life of Nisha; the pastor provided her with microcredit and spiritual support during services and other religious practices in his ministry.

What is interesting here is that if one only uses classical methods of observation, what is discovered is classical pastoral power. This does not help us discover the activities of resilience; selling, eating, walking. Within this classical method of observation Nisha is the object of pastoral power, yet she uses it to protect and build her family. Hence, there are traces of agency and resilience within classical pastoral power observation methodology that are waiting to be discovered through surprise.

Nevertheless, what is most striking are the reflections that develop when the decolonial gaze is activated. All three narratives invite us into power ruptures and ecclesial disobedience. The selling, the eating, and the walking are three embodied practices that disrupt. However, they are, at the same time, three embodied practices that restart a different epistemic enunciation. Given the presupposition that ecclesia is the surprise when God reveals the unexpected and gives people the right to have their own agency, these narratives belong to the discovery of that (decolonial) epistemology.

Therefore, theology, given that it becomes an interpretation of the everyday, can discover a late modern decentering counter-conduct. It is, like Foucault thought, still located in theological traditions, but the traditions and perspectives differ from those Foucault analysed. Foucault collected his material in accepted sources of (eschatological and mystical) theology. The decolonial departs from theological traditions, and therefore trading, eating and walking are possible starting points, not the conclusion, nor the governmentality of pastoral power. Linking counter-conducts with the genuine interest of the decolonial, is an opening for a theology of the decolonial. In a 
recent book Mignolo and Walsh (2018:27) refer to the Ecuadorian Escobar; 'Similarly ... it is to recall Arturo Escobar's argument made over a decade ago about 'the need to take seriously the epistemic force of local histories and to think theory from the political praxis of subaltern groups'. For Mignolo and Walsh these stories are part of an unheard story. The stories that Mignolo and Walsh present are, however, not stories like Nisha's. They went to more obviously resistant contexts to collect and reflect. Yet, in the context of theology, there are stories, and narratives, like those of Nisha. Theology becomes important and challenging when it walks with and reflects on what the embodied participation might mean - theologically.

\section{Decentering Counter-conducts and Traces of a Decolonial Theology}

The three narratives above could be interpreted as three unexpected late modern, counter-conducts. There is the (ecclesiologically decentered) counterconduct of vulnerable respatialisation, the counter-conduct of vulnerable sharing, and the counter-conduct of vulnerable agency. The decentering is what unifies the three narratives. Nisha walks and senses the township; she touches the skin of her fellow migrant neighbors as well as the skin of some of her Zulu neighbours. The reception, the entanglement of earth, smells, expectations and colors, with the pastor two steps behind, make this walk theologically significant. It is a 'liberation theology' that liberates by resigning, and that encourages by recognising that black bodies matter. This happens when one shares a meal, walks the walk and is near the selling. The involved researcher and decolonial reflection belong together. The theology of counter-conduct embodied in Nisha's walk is when the researcher senses that Nisha takes the lead and builds ecclesiology. Through this the power structures of the colonial church are almost dissolved. It is Nisha in her sensory and sensible relations to the earth, smells and humans that mark the start of a theological counter-conduct beyond modernity. And the counter-conduct dissolves the ecclesial moment.

\section{References}

Adogame, A. 2010. Transnational Migration and Pentecostalism in Europe. PentecoStudies 9,1: 56 - 73. 
Ahmed, S. 2000. Strange Encounters. London: Routledge.

Foucault, M. 1982. The Subject and Power. Critical Inquiry 8,4: 777 - 795.

Foucault, M. 1994. Omnes et Singulatim: Toward a Critique of Political

Reason. In Faubion, J. (eds.): Power: Essential Works of Foucault 1954 1984. New York: The New Press.

Foucault, M. 2007. Security, Territory, Population. New York: Palgrave Macmillan.

Greenburg, J. 2010. The Spatial Politics of Xenophobia: Everyday Practices of

Congolese Migrants in Johannesburg. Transformation: Critical Perspectives on Southern Africa 74: 66 - 86.

Heimbrock, H-G. \& T. Wyller 2019. (forthcoming.) Challenging Ecclesiological Traditions. In Angell, S., K.H. Johansen \& A. Vahänkagas (eds.):

Reforming: Space, Body and Politics. Tübingen: IAPT Conference Proceedings.

Mignolo, W. 2011. The Darker Side of Western Modernity. Durham: Duke University Press.

Mignolo, W. \& C. Walsh 2018. On Decoloniality. Concepts. Analytics. Praxis. Durham: Duke University Press.

Sander, H-J., K. Villadsen \& T. Wyller 2016 The Spaces of Others Heterotopic Spaces. Practicing and Theorizing Hospitality and CounterConduct beyond the Religion/ Secular Divide. Göttingen: Vandenhoeck \& Ruprecht

Settler, F. 2018. A Postcolonial Perspective on Religion and Migration. In Machado, D., B. Turner \& T. Wyller (eds.): Borderland Religion. London: Routledge.

Wyller, T. 2018. Touching and Contamination: What the Xenophobes want to Avoid. Reflections from a Congolese Borderland in South Africa. In Machado, D., B. Turner \& T. Wyller (eds.): Borderland Religion. London: Routledge.

Trygve Wyller Systematic Theology Faculty of Theology University of Oslo School of Religion, Philosophy and Classics, University of KwaZulu-Natal t.e.wyller@teologi.uio.no 